\title{
日本コンピュータ外科学会選奨結果報告
}

本学会では 2001 年度より選奨制度を開始し、コンピュータ外科学の領域に貢献する学術および関 連事業における業績を選奨してきました。ここに 2013 年度講演論文賞の選奨結果をご報告します。 本賞は 2013 年度日本コンピュータ外科学会大会で発表された講演論文を対象とし、コンピュータ外 科学の発展に大きく貢献する論文を表彰するものです。

受賞者の方々の益々のご発展をご祈念申しあげますとともに、会員の皆様におかれましては本選奨 制度へのご理解と、本学会への相変わらぬ積極的なご参加とご支援をお願いいたします。

2013 年度選奨委員会副委員長 篠原一彦 (東京工科大学)

\section{2013 年度講演論文賞}

○最優秀賞／13(IV)-14 頭蓋底手術における3D バーチャル画像と 3D プリンタにより造形された立体モデル による手術支援の検討.

林雄一郎，藤井正純，藤本保志，梶田泰一，若林俊彦，森 健策.

JJSCAS 2013;15(2):132-133.

O 13(IV)-18 医工産学連携による「肝変形を可能とした次世代型 3D-CG 肝臓手術シミュレーション・システム」 開発.

大城幸雄，金 尚泰，工藤博幸，滝沢穂高，三谷 純，岩田洋夫，矢野博明，掛合英紀，圓崎祐貴，清徳省雄， 大河内信弘.

JJSCAS 2013;15(2):140-141.

○ 13(VIII)-35 手術支援用マスタ・スレーブにおける身体所有感移転に基づく操作性向上に関する基礎研究. 荒田純平，服部将士，市川翔平，坂口正道，橋爪 誠.

JJSCAS 2013;15(2):174-175.

○ 13(XIII)-57 カオス解析を用いた内視鏡外科手術における鉗子先端動作解析

〜熟練者と初心者の潜在的な動きの違い〜．

植村宗則，富川盛雅，苗 鉄軍，家入里志，宗崎良太，大内田研宙，橋爪 誠.

JJSCAS 2013;15(2):218-219 


\section{日本コンピュータ外科学会 2013 年度選奨委員会}

委 員 長 渡辺英寿 自治医科大学脳神経外科

副委員長 篠原一彦 東京工科大学医療保健学部

委 員 浅原利正 広島大学

伊関 洋 東京女子医科大学大学院 先端工学外科学分野

大西五三男 国際医療福祉大学

加藤天美 大阪大学大学院 医学系研究科

小杉幸夫東京工業大学総合理工学研究科

小林寿光 国立がん研究センター

佐久間一郎 東京大学大学院工学系研究科

佐藤嘉伸大阪大学大学院医学系研究科

菅野伸彦 大阪大学大学院医学系研究科

杉町圭蔵 おんが病院

土肥健純東京電機大学工学部

友田幸一関西医科大学耳鼻咽喉科

橋爪 誠 九州大学大学院医学研究院

橋本大定東和病院

幹 事 苗村 潔 東京工科大学医療保健学部 